\title{
ANALISIS PENGARUH PENGETAHUAN INVESTASI, PELATIHAN PASAR MODAL, MODAL INVESTASI MINIMAL DAN PERSEPSI RISIKO TERHADAP MINAT INVESTASI MAHASISWA DI PASAR MODAL (STUDI PADA PT PHINTRACO SEKURITAS BRANCH OFFICE SEMARANG)
}

\author{
Theresia Tyas Listyani*), Muhammad Rois*), Slamet Prihati, \\ Program Studi D4 Analis Keuangan, Jurusan Akuntansi
}

Jl. Prof. H. Soedarto, S. H., Tembalang, Kota Semarang, Jawa Tengah 50275

\begin{abstract}
Abstrak: Penelitian ini bertujuan untuk menganalisis pengaruh pengetahuan investasi, pelatihan pasar modal, modal investasi minimal dan persepsi risiko terhadap minat investasi mahasiswa di pasar modal (studi pada PT Phintraco Sekuritas Branch Office Semarang). Desain penelitian ini merupakan penelitian kuantitatif terapan kausal. Data yang digunakan adalah data primer dan data sekunder. Metode pengumpulan data menggunakan kuesioner. Teknik pengambilan sampel yang digunakan adalah teknik purposive sampling, dan jumlah sampel sebanyak 98 responden. Uji coba instrumen dianalisis menggunakan uji validitas dan uji reliabilitas. Metode analisis data yang digunakan adalah Analisis Regresi Linier Berganda. Hasil penelitian uji t menunjukkan, bahwa pengetahuan investasi dan persepsi risiko tidak berpengaruh terhadap minat investasi mahasiswa. Pelatihan pasar modal dan modal investasi minimal berpengaruh terhadap minat investasi mahasiswa. Hasil penelitian uji $\mathrm{F}$ menunjukkan, pengetahuan investasi, pelatihan pasar modal, modal investasi minimal dan persepsi risiko secara simultan berpengaruh terhadap minat investasi mahasiswa.

Kata kunci: Pengetahuan Investasi, Pelatihan Pasar Modal, Modal Investasi Minimal, dan Persepsi Risiko.
\end{abstract}

Abstract: The purpose of research is to analyse the effects of investment knowledge,
capital market training, minimum investment capital and risk perception on student
investment interest in capital market (study at PT Phintraco Sekuritas Branch Office
Semarang). The design of this study is a causally applied quantitative research. The
data used are primary data and secondary data. Method of collecting data used
questioner. The sampling technique used was purposive sampling, and the amount of
the sample are 98 respondents. The test of the instruments was analysed by using
validity test and realibility test. Data analysis method used is Multiple Linear
Regression Analysis. The result of t test showed that investment knowledge and risk
perception had no effect toward student investment interest. Capital market training
and minimum investment capital had an effect toward student investment interest.
Investment knowledge, capital market training, minimum investment capital and
risk perception simultaneously effect the student investment interest. Keyword: Investment Knowledge, Capital Market Training, Minimum Investment Capital and Risk Perception. 


\section{PENDAHULUAN \\ Latar Belakang}

Perkembangan ekonomi dan teknologi saat ini, memberikan kemudahan kepada perusahaan untuk selalu meningkatkan dan mengembangkan bisnisnya. Perusahaan dapat melakukannya dengan memanfaatkan fasilitas teknologi. Perkembangan bisnis dalam perusahaan akan berdampak terhadap meningkatnya daya saing antar perusahaan, sehingga setiap perusahaan dituntut untuk selalu mengembangkan strateginya. Menurut Pajar dan Pustikaningsih (2017: 2), salah satu bentuk strategi perusahaan dalam menunjang kinerjanya adalah dengan bergabung dan aktif di pasar modal.

Hadirnya pasar modal memiliki peranan penting bagi para investor, baik investor individu maupun badan usaha. Hal ini dikarenakan, para investor yang memiliki kelebihan dana dapat menyalurkan dananya untuk diinvestasikan kepada para pengusaha, sehingga para pengusaha bisa memperoleh tambahan dana yang dapat digunakan untuk memperluas jaringan usahanya melalui para investor di pasar modal.

Semenjak dibukanya Bursa Efek Indonesia pada tahun 2007, investasi di pasar modal menjadi salah satu bentuk alternatif investasi yang mudah diakses dan sering digunakan oleh masyarakat luas. Hal tersebut dibuktikan, dengan bertambahnya jumlah investor di Indonesia dan tingginya jumlah perdagangan saham di Bursa Efek Indonesia.

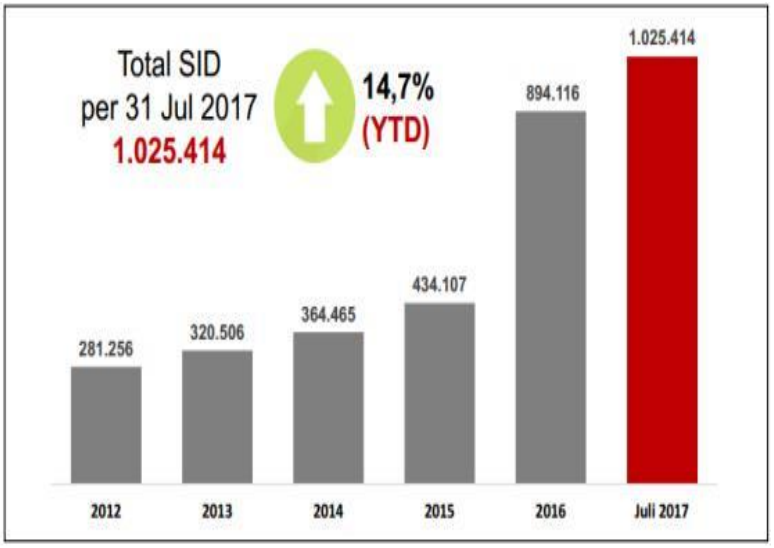

Gambar 1.1 Grafik Pertumbuhan SID 2012 - Juli 2017

Sumber: www.ksei.co.id

PT Kustodian Sentral Efek peningkatan sebesar 3,57\% dari bulan Indonesia (KSEI) telah mencatat adanya peningkatan jumlah investor, yang dilihat melalui Single Investor Identification (SID) sebesar 782.511 atau $14,7 \%$ dari 894.116 per 2016 menjadi 1.025.414 per Juli tahun 2017. Peningkatan Single Investor Identification (SID) juga terjadi pada PT Phintraco Sekuritas yang ada di Provinsi Jawa Tengah, termasuk PT Phintraco Sekuritas Branch Office Semarang. PT Phintraco Sekuritas mencatat 3.274 investor pada 30 November 2017, atau mengalami sebelumnya pada tahun yang sama. Investor tersebut merupakan investor muda usia 18-25 tahun, yang diklasifikasikan sebagai mahasiswa. Dalam sebuah wawancara, Fanny Rifqi El Fuad Kepala Bursa Efek Indonesia Cabang Semarang mengatakan bahwa mahasiswa merupakan segmentasi utama sebagai investor pasar modal. Hal ini dikarenakan, mahasiswa memiliki keunggulan yaitu kekayaan usia dibandingkan dengan karyawan, ibu rumah tangga dan pensiunan. 
Namun, peningkatan jumlah investor muda yang dicapai PT Phintraco Sekuritas menunjukkan adanya perbedaan dengan tingkat pertumbuhan jumlah investor yang ada. Pertumbuhan jumlah investor muda pada PT Phintraco Sekuritas mengalami penurunan sebesar 106 investor atau sebesar 48,4\%, dari 219 pada tanggal 30 Oktober 2017 menjadi 113 pada tanggal 30 November 2017.

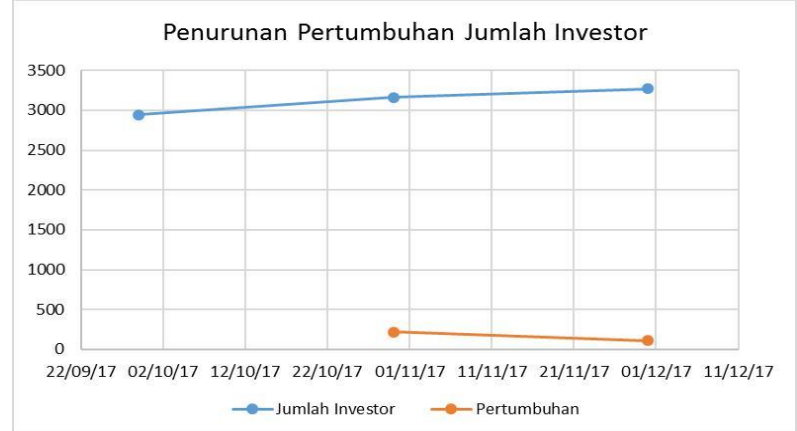

Penurunan pertumbuhan jumlah investor pada PT Phintraco Sekuritas dimungkinkan, karena rendahnya motivasi atau minat investasi mahasiswa terhadap pasar modal. Menurut Merawati dan Putra (2015: 106), rendahnya animo atau minat investasi mahasiswa di pasar modal, dikarenakan aktivitas investasi pada bursa efek saat ini masih tergolong baru di Indonesia dibandingkan dengan negara lain. Selain rendahnya animo masyarakat, hal ini juga disebabkan rendahnya pemahaman dan pengetahuan masyarakat baik pengusaha maupun mahasiswa mengenai investasi di pasar modal.

Pengetahuan dasar investasi merupakan hal yang sangat penting untuk diketahui oleh calon investor. Hal ini bertujuan, agar para investor (mahasiswa) terhindar dari praktikpraktik investasi yang tidak rasional (judi), budaya ikut-ikutan, penipuan dan risiko kerugian, maka diperlukan pengetahuan, pengalaman serta naluri bisnis untuk menganalisis efekefek mana yang akan dibeli dalam melakukan investasi di pasar modal (Halim, 2005:4).

Teori tersebut sesuai dengan penelitian yang dilakukan Merawati dan Putra (2015), mengenai kemampuan pelatihan pasar modal memoderasi pengaruh pengetahuan investasi dan penghasilan pada minat berinvestasi mahasiswa menghasilkan pengetahuan investasi berpengaruh positif terhadap minat investasi mahasiswa. Hasil penelitian Merawati dan Putra (2015) didukung oleh penelitian Pajar dan Pustikaningsih (2017), yang menyatakan pengetahuan investasi berpengaruh terhadap minat berinvestasi mahasiswa FE UNY di pasar modal.

Pengetahuan investasi menjadi catatan penting bagi para mahasiswa untuk memulai investasi di pasar modal, tetapi mahasiswa juga memerlukan pelatihan pasar modal. Pelatihan Pasar Modal (PPM) merupakan salah satu program edukasi tentang pasar modal yang diadakan oleh Bursa Efek Indonesia, yang bekerjasama dengan PT. Kustodian Sentral Efek Indonesia (KSEI), PT. Kliring Penjaminan Efek Indonesia (KPEI) beserta perusahaanperusahaan sekuritas.

Program edukasi ini sesuai dengan Theory of Planned Behavior menyatakan, poin utama yang mampu digunakan untuk memprediksi perilaku adalah intensi tingkah laku (Ajzen dalam Merawati dan Putra, 2015: 107). Hal tersebut menjelaskan, jika seseorang yang memiliki minat berinvestasi, maka kemungkinan melakukan tindakan untuk mencapai keinginan berinvestasi tinggi. Tindakan yang dilakukan antara lain, mengikuti pelatihan dan seminar tentang investasi, menerima dengan 
baik penawaran investasi dan berakhir dengan melakukan investasi (Kusmawati, 2011:104).

Dalam Pelatihan Pasar Modal (PPM),Bursa Efek Indonesia juga mendirikan Galeri Investasi sebagai bentuk kerjasama dengan institusi pendidikan. Galeri Investasi didirikan dengan tujuan, agar mahasiswa lebih mengetahui tentang pasar modal, memahami pentingnya berinvestasi, mengenal saham sebagai alat investasi yang ideal, dan memahami kendala dalam berinvestasi di pasar modal (Hermanto, 2017).

Salah satu kendala dalam berinvestasi di pasar modal bagi mahasiswa adalah dana atau modal awal. Kendala ini dikarenakan, mayoritas penghasilan yang didapatkan mahasiswa berasal dari pemberian orang tua. Kemudian beasiswa, hadiah atau bonus, dan yang terakhir berasal dari pendapatan pribadi atau pekerjaan sampingan yang dimiliki (Pajar dan Pustikaningsih, 2017). Kendala ini menjadi masalah yang perlu diperhatikan untuk perusahaanperusahaan sekuritas, disebabkan mahasiswa merupakan segmentasi utama sebagai investor pasar modal. Oleh karena itu, untuk mengatasi masalah tersebut, perusahaanperusahaan sekuritas menawarkan dana awal yang harus disetorkan untuk membuat account, hanya dengan Rp100.000,00 termasuk pada PT Phintraco Sekuritas.

Dalam konteks investasi, mahasiswa juga perlu mempelajari tentang risiko investasi. Risiko investasi merupakan kemungkinan terjadinya perbedaan antara return yang diharapkan dengan return aktual (Tandelilin, 2017: 101). Semakin besar return yang diperoleh, maka semakin tinggi risiko yang akan diperoleh. Return merupakan salah satu faktor yang memotivasi investor, dan juga merupakan imbalan atas keberanian investor dalam menanggung risiko atas ivestasi yang dilakukannya (Tandelilin, 2017:102).

Penelitian mengenai hubungan persepsi risiko telah dilakukan oleh Raditya dkk (2014), mengenai pengaruh modal investasi minimal di BNI Sekuritas, return dan persepsi terhadap risiko pada minat investasi mahasiswa dengan penghasilan sebagai variabel moderasi, yang menyatakan persepsi risiko berpengaruh terhadap minat investasi mahasiswa.

Berdasarkan latar belakang masalah tersebut, penelitian ini dilakukan untuk mengetahui bagaimana meningkatkan minat investasi mahasiwa di pasar modal melalui pengetahuan investasi, pelatihan pasar modal, modal investasi minimal dan persepsi risiko pada PT Phintraco Sekuritas Branch Office Semarang? Oleh karena itu, penelitian ini diberi judul "Analisis Pengaruh Pengetahuan Investasi, Pelatihan Pasar Modal, Modal Investasi Minimal dan Persepsi Risiko Terhadap Minat Investasi Mahasiswa di Pasar Modal (Studi pada PT Phintraco Sekuritas Branch Office Semarang)".

Adapun permasalahan yang akan dibahas dalam penelitian ini adalah bagaimana pengetahuan investasi berpengaruh terhadap minat investasi mahasiswa di pasar modal pada PT Phintraco Sekuritas Branch Office Semarang?. Pertanyaan ini digunakan untuk menganalisa pengaruh pengetahuan investasi terhadap minat investasi mahasiswa di pasar modal pada PT Phintraco Sekuritas Branch Office Semarang. Selanjutnya untuk menganalisa pengaruh pelatihan pasar modal terhadap minat investasi mahasiswa di pasar modal pada PT Phintraco Sekuritas Branch Office Semarang, maka permasalahan yang diajukan adalah bagaimana pelatihan pasar modal berpengaruh terhadap minat investasi mahasiswa di pasar modal pada PT Phintraco Sekuritas Branch Office Semarang? 
Permasalahan yang diajukan selanjutnya adalah bagaimana modal investasi minimal berpengaruh terhadap minat investasi mahasiswa di pasar modal pada PT Phintraco Sekuritas Branch Office Semarang? digunakan untuk menganalisa pengaruh modal investasi minimal terhadap minat investasi mahasiswa di pasar modal pada PT Phintraco Sekuritas Branch Office Semarang. Permasalahn terakhir yang diajukan adalah bagaimana persepsi risiko berpengaruh terhadap minat investasi mahasiswa di pasar modal pada PT Phintraco Sekuritas Branch Office Semarang? digunakan untuk menganalisa pengaruh persepsi risiko terhadap minat investasi mahasiswa di pasar modal pada PT Phintraco Sekuritas Branch Office Semarang.

\section{LANDASAN TEORI}

Teori Tindakan Beralasan (Theory of Reasoned Action) dan Teori Perilaku Berencana (Theory of Planned Behavior)

Theory of Reasoned Action
menjelaskan, bahwa perilaku
seseorang ditentukan oleh suatu
intensi yang merupakan fungsi dan
tingkah laku terhadap perilaku
norma subyektif. Intensi ini
ditentukan oleh tiga hal, yaitu
tingkah laku, norma subyektif dan
pengendalian perilaku. Theory of
Planned Behavior yang merupakan
perluasan dari Theory of Reasoned
Action. Theory of Planned Behavior
didasarkan pada asumsi manusia
sebagai mahluk rasional dan
menggunakan informasi-informasi
yang diperoleh secara sistematis.
Orang memikirkan implikasi dari
tindakan mereka sebelum mereka
memutuskan untuk melakukan atau
tidak melakukan perilaku tertentu.
Theory of Planned Behavior
menyatakan, poin utama yang
mampu digunakan untuk
memprediksi perilaku adalah intensi
tingkah laku (Ajzen dalam Merawati
dan Putra, 2015: 107).

\section{Minat Investasi Mahasiswa}

Minat merupakan fungsi kejiwaan atau sambutan yang sadar untuk tertarik terhadap suatu obyek baik berupa benda atau yang lain, sedangkan investasi diartikan sebagai komitmen atas sejumlah dana atau sumber daya lainnya yang dilakukan saat ini, dengan tujuan memperoleh keuntungan di masa datang (Tandelilin, 2017: 2).

Minat investasi merupakan hasrat atau keinginan yang kuat pada seseorang untuk mempelajari segala hal yang berkaitan dengan investasi hingga pada tahap mempraktikannya, yaitu berinvestasi (Pajar dan Pustikaningsih, 2017). Ciri-ciri seseorang yang berminat untuk berinvestasi dapat diketahui dari besar usaha mereka dalam mencari suatu jenis investasi dari keuntungan, kelemahan dan kinerja investasi. Kemudian, mereka melakukan investasi pada jenis investasi yang telah dipelajari atau menambah porsi atau bobot investasi yang sudah ada sebelumnya (Kusmawati, 2011: 104).

\section{Pengetahuan Investasi}

Edukasi investasi merupakan persepsi tentang pengetahuan atau ilmu yang telah diberikan, baik kepada mahasiswa melalui universitas atau dari pihak eksternal mengenai investasi di pasar modal (Hermanto, 2017). Pengetahuan investasi merupakan pemahaman yang harus dimiliki seseorang tentang berbagai aspek mengenai investasi, dimulai dari pengetahuan dasar penilaian investasi, tingkat risikonya dan tingkat pengembalian (return) investasi (Pajar dan Pustikaningsih, 2017: 7). 
Menurut Kusmawati (2011), pengetahuan yang memadai tentang instrumen investasi dan cara menilai kinerja perusahaan sangat diperlukan untuk menghindari kerugian dan mendapat keuntungan yang maksimal ketika berinvestasi di pasar modal.

\section{Pelatihan Pasar Modal}

Pelatihan Pasar Modal (PPM) merupakan salah satu program edukasi tentang pasar modal yang diadakan oleh Bursa Efek Indonesia, yang bekerjasama dengan PT. Kustodian Sentral Efek Indonesia (KSEI), PT. Kliring Penjaminan Efek Indonesia (KPEI) beserta perusahaan-perusahaan sekuritas. Dalam Pelatihan Pasar Modal (PPM), Bursa Efek Indonesia juga mendirikan Galeri Investasi sebagai bentuk kerjasama dengan institusi pendidikan.

Galeri Investasi didirikan dengan tujuan, agar mahasiswa lebih mengetahui tentang pasar modal, memahami pentingnya berinvestasi, mengenal saham sebagai alat investasi yang ideal, dan memahami kendala dalam berinvestasi di pasar modal (Hermanto, 2017). Materi pelatihan yang diberikan seputar jenis investasi dan cara atau teknik awal dalam berinvestasi, sehingga mahasiswa mampu memilih jenis investasi dan mengelola investasinya berdasarkan pengetahuan atas return dan risiko yang akan di hadapi (Merawati dan Putra, 2017: 107).

\section{Modal Minimum Investasi}

Modal minimum investasi merupakan modal awal yang digunakan dalam melakukan investasi oleh calon investor (Hermanto, 2017). PT Phintraco Sekuritas menawarkan dana awal yang harus disetorkan untuk membuat account, hanya dengan Rp100.000,00. Jumlah pembelian minimal yang ditetapkan oleh BEI adalah seratus lembar, dan harga minimal adalah Rp50,00 per lembar, sehingga investasi minimalnya adalah Rp5.000,00.

\section{Persepsi Risiko}

Persepsi merupakan pengalaman yang dihasilkan melalui indra penglihatan, pendengaran, penciuman dan lainnya yang ditunjukkan dengan adanya perubahan perilaku dalam diri seseorang. Persepsi risiko, didefinisikan sebagai ketidakpastian yang dihadapi oleh konsumen (investor) ketika konsumen (investor) tidak dapat meramalkan dampak dari keputusan pembelian atau investasi (Suhir dkk, 2017: 4). Persepsi risiko dibentuk secara sosial sebagai hasil dari banyak faktor yang menjadi dasar dari perbedaan pengambilan keputusan terhadap kemungkinann kerugian (Wulandari dan Iramani, 2014: 57).

\section{METODE PENELITIAN}

\section{Desain Penelitian}

Desain penelitian yang digunakan dalam penelitian ini adalah penelitian kuantitatif terapan kausal. Penelitian kuantitatif digunakan untuk menguji hipotesis yang telah ditetapkan. Penelitian terapan digunakan untuk memcahkan masalah, sedangkan penelitian kausal digunakan untuk mengetahui hubungan sebab akibat (Sugiyono, 2010). Jenis data yang digunakan 
adalah data primer, dengan metode pengumpulan data kuesioner, wawancara dan studi kepustakaan.Kuesioner yang diberikan kepada responden pada penelitian ini berisi pertanyaan tertutup. Penyebaran kuesioner pada responden dilakukan secara langsung dan tidak langsung yaitu melalui google form kuesioner. Pengukuran variabel dalam kuesioner diukur menggunkan skala likert.

\section{Populasi dan Sampel}

Populasi merupakan seluruh karakteristik/sifat yang dimiliki subyek atau obyek yang telah ditetapkan peneliti (Sugiyono, 2010). Populasi dalam penelitian ini adalah seluruh mahasiswa yang melakukan investasi di pasar modal pada perusahaan PT Phintracho Sekuritas Branch Office Semarang, dengan menggunkan teknik pengambilan sampel purposive sampling yang menurut Sugiyono (2009: 122), merupakan teknik pengambilan sampel menggunakan pertimbangan tertentu. Penentuan jumlah ukuran sampel dalam penelitian ini menggunakan metode Slovin.

Rumus Slovin adalah $\mathrm{n}=\frac{\mathrm{N}}{\mathrm{N} \cdot \mathrm{e}^{2}+1}$

Pertimbangan penentuan sampel dalam penelitian ini adalah mahasiswa yang masih aktif kuliah, mahasiswa yang membuka rekening efek di PT Phintraco Sekuritas Branch Office Semarang dan mahasiswa yang aktif melakukan transaksi jual beli saham minimal empat kali dalam sebulan.

\section{Pengolahan Data \\ Pengolahan data bertujuan} mengubah data mentah dari hasil pengukuran menjadi data yang lebih halus sehingga memberikan arah untuk melakukan pengkajian lebih lanjut (Hasan, 2010). Metode pengolahan data yang digunakan dalam penelitian ini adalah editing, coding, dan tabulasi. Editing digunakan untuk menghilangkan kesalahan-kesalahan yang terdapat pada pencatatn di lapangan dan bersifat korelasi. Coding merupakan pemberian kode pada setiap data yang termasuk dalam kategori yang sama dan tabulasi merupakan pembuatan tabel yang berisikan berbagai data yang sudah diberi kode sesuai dengan analisis yang dibutuhkan (Hasan, 2010).

\section{Variabel Penelitian}

Menurut Sugiyono (2013: 38), variabel adalah suatu atribut atau sifat atau nilai dari orang, obyek atau kegiatan yang mempunyai variasi tertentu yang ditetapkan oleh peneliti untuk dipelajari dan kemudian ditarik kesimpulannya. Variabel yang digunakan dalam penelitian ini adalah sebagai berikut:

\section{Variabel Dependen}

Variabel dependen atau variabel terikat merupakan variabel yang dipengaruhi atau yang menjadi akibat, karena adanya variabel bebas (Sugiyono, 2010: 59). Variabel dependen dalam penelitian ini adalah minat investasi mahasiswa.

Minat investasi merupakan hasrat atau keinginan yang kuat pada seseorang untuk mempelajari segala hal yang berkaitan dengan investasi 
hingga sampai pada tahap mempraktikannya, yaitu berinvestasi (Pajar dan Pustikaningsih, 2017). Variabel minat investasi mahasiswa diukur dengan menggunakan instrumen yang diadaptasikan dan dikembangkan dari penelitian Khoirunnisa (2017). Variabel minat investasi mahasiswa diukur menggunakan skala likert 5 poin.

\section{Variabel Independen}

Variabel independen atau variabel bebas merupakan variabel yang mempengaruhi atau yang menjadi sebab perubahannya atau timbulnya variabel dependen (Sugiyono, 2010: 59). Variabel independen dalam penelitian ini adalah pengetahuan investasi, pelatihan pasar modal, modal investasi minimal dan persepsi risiko.

\section{Pengetahuan Investasi}

Pengetahuan investasi diartikan sebagai pemahaman yang harus dimiliki seseorang tentang berbagai aspek mengenai investasi, dimulai dari pengetahuan dasar penilaian investasi, tingkat risikonya dan tingkat pengembalian (return) investasi (Pajar dan Pustikaningsih, 2017: 7). Variabel pengetahuan investasi diukur dengan menggunakan instrumen yang diadaptasikan dan dikembangkan dari penelitian Khoirunnisa (2017). Variabel minat investasi mahasiswa diukur menggunakan skala likert 5 poin.

\section{Pelatihan Pasar Modal}

Pelatihan Pasar Modal (PPM) merupakan salah satu program edukasi tentang pasar modal yang diadakan oleh Bursa Efek Indonesia, yang bekerjasama dengan PT. Kustodian Sentral Efek Indonesia (KSEI), PT. Kliring Penjaminan Efek Indonesia (KPEI) beserta perusahaan-perusahaan sekuritas.

\section{Modal Investasi Minimal}

Modal minimum investasi merupakan modal awal yang digunakan dalam melakukan investasi oleh calon investor (Hermanto, 2017). PT Phintraco Sekuritas menawarkan dana awal yang harus disetorkan untuk membuat account, hanya dengan Rp100.000,00.

\section{Persepsi Risiko}

Persepsi risiko menurut Suhir dkk (2017: 4), didefinisikan sebagai ketidakpastian yang dihadapi oleh konsumen (investor) ketika konsumen (investor) tidak dapat meramalkan dampak dari keputusan pembelian atau investasi.

\section{Metode Analisis Data}

Instrumen penelitian adalah suatu alat yang digunakan untuk mengukur fenomena alam maupun fenomena sosial yang diamati atau yang biasa disebut dengan variabel penelitian yang diamati (Sugiyono, 2010: 146). Dalam penelitian kuantitatif, kualitas instrumen penelitian berkenaan dengan valid dan reliabel. Untuk mengukur instrumen dalam penelitian ini menggunakan dua uji, yaitu uji validitas dan uji reliabilitas.

Uji validitas dalam penelitian ini dilakukan dengan cara mengkorelasikan antar skor item dengan skor total item dan digunakan untuk mengukur valid tidaknya suatu kuesioner. Uji 
reliabilitas digunakan untuk mengukur reliabel atau konsistensi pernyataan atau indikator dari variabel penelitian (Ghozali, 2011).

\section{Analisis Regresi Linier Berganda}

Analisis regresi adalah studi mengenai ketergatungan variabel dependen (terikat) dengan satu atau lebih variabel independen (variabel penjelas/bebas), dengan tujuan untuk mengestimasi dan/atau memprediksi rata-rata populasi atau nilai rata-rata variabel dependen berdasarkan nilai variabel independen yang diketahui (Ghozali, 2011).

Alasan menggunakan metode ini, dikarenakan analisis ini dapat menjawab pertanyaan-pertanyaan terkait dengan: seberapa jauh variasi perubahan minat investasi mahasiswa mampu dijelaskan oleh pengetahuan investasi, pelatihan pasar modal, modal investasi minimal dan persepsi risiko?; diantara pengetahuan investasi, pelatihan pasar modal, modal investasi minimal dan persepsi risiko manakah yang memberikan pengaruh paling tinggi terhadap minat investasi mahasiswa di pasar modal pada PT Phintracho Sekuritas Branch Office Semarang?; sudahkan keseluruhan pengetahuan investasi, pelatihan pasar modal, modal investasi minimal dan persepsi risiko mampu memprediksi minat investasi mahasiswa di pasar modal?; apakah prediksi minat investasi mahasiswa di pasar modal dengan pengetahuan investasi, pelatihan pasar modal, modal investasi minimal dan persepsi risiko sudah layak menjadi model penelitian?

\section{Uji Asumsi Klasik}

Menurut Ghozali (2011, 96), analisis linear berganda berlandaskan pada teknik estimasi Ordinary Least Squares (OLS). Model regresi dari metode OLS merupakan model regresi yang memberikan estimator linear yang tidak bias atau memiliki ketepatan dan akan memberikan hasil terbaik yang Best Linear Unbiased Estimator (BLUE), jika memenuhi semua uji asumsi klasik. Pengujian dalam asumsi klasik, terdiri dari uji linearitas, uji normalitas, uji multikolinieritas dan uji heteroskedastisitas.

\section{Uji Linearitas}

Uji linearitas digunakan untuk melihat apakah spesifikasi model yang digunakan sudah benar atau tidak, apakah fungsi yang digunakan dalam suatu empiris sebaiknya berbentuk linier, kuadrat atau kubik. Alasan penggunaan uji linieritas adalah untuk membantu menguatkan justifikasi, bahwa model regresi yang dibangun benar memiliki hubungan linearitas. Dalam penelitian ini uji linearitas yang dilakukan adalah dengan menggunakan Uji Durbin Watson (DW test). Uji ini digunakan untuk melihat apakah sebaiknya model regresi linear atau kuadrat (Ghozali, 2011).

\section{Uji Normalitas}

Uji normalitas bertujuan untuk menguji apakah dalam model regresi, variabel penganggu atau residual memiliki distribusi normal (Ghozali, 2011: 160). Pengujian normalitas dalam penelitian ini menggunakan analisis grafik dan uji statistik. Analisis grafik dilakukan 
dengan menggunakan normal probability plot, karena analisis grafik yang lebih handal daripada hanya dengan melihat grafik histogram untuk melihat normalitas residual. Distribusi normal akan membentuk satu garis lurus diagonal, dan ploting data residual akan dibandingkan dengan garis diagonal (Ghozali, 2011). Analisis statistik yang digunakan dalam penelitian ini, dengan menggunakan uji statistik non-parametrik Kolmogorov-Smirnov (K-S).

\section{Uji Multikolinieritas}

Menurut Ghozali (2011: 105), uji multikolinieritas bertujuan untuk menguji apakah model regresi ditemukan adanya korelasi antar variabel bebas (independen). Multikolonieritas diuji dengan Tolerance dan Variance Inflation Factor (VIF). Tolerance mengukur variabilitas variabel independen yang terpilih yang tidak dijelaskan oleh variabel independen lainnya. Kriteria pengambilan keputusan untuk uji multikolinieritas dengan tolerance dan variance inflation factor (VIF). Model regresi dikatakan tidak terdapat multikolinieritas, apabila nilai Tolerance $>0,10$ atau sama dengan $\mathrm{VIF}<10$.

\section{Uji Heteroskedastisitas}

Uji heteroskedastisitas bertujuan menguji apakah dalam model regresi terjadi ketidaksamaan variance dari residual satu pengamatan ke pengamatan yang lain. Pengujian untuk mendeteksi ada atau tidaknya heteroskedastisistas dalam penelitian ini menggunakan uji grafik dan uji glejser. Pengujian dengan uji grafik adalah dengan melihat ada tidaknya pola tertentu pada grafik scatterplot. Uji glejser dilakukan untuk meregres nilai absolut residual terhadap variabel independen (Ghozali, 2011: 142).

\section{Uji Kelayakan Model \\ Uji Statistik F}

Uji $F$ merupakan uji yang digunakan untuk menilai apakah model yang diestimasi layak digunakan untuk menjelaskan pengaruh variabel independen terhadap varaibel dependen, sebagai suatu model yang utuh untuk memecahkan masalah (Ghozali, 2011).

Uji F dalam penelitian ini digunakan untuk menguji kelayakan model yang dihasilkan dengan menggunakan uji kelayakan model pada tingkat a sebesar 5\%. Jika nilai signifikan $<0,05$, maka model yang digunakan dalam penelitian layak dan dapat dipergunakan analisis berikutnya.

Uji t

Uji t digunakan untuk menguji satu variabel penjelas/independen secara indivisual dalam menerangkan variasi variabel dependen (Ghozali, 2011: 98).

Pengujian secara parsial dalam penelitian ini menggunakan tingkat level of signifikan $a=5 \%$. Apabila signifikansi uji $\mathrm{t}<0,05$, maka $\mathrm{H} 0$ yang menyatakan pengetahuan investasi, pelatihan pasar modal, modal investasi minimal dan persepsi risiko tidak memiliki pengaruh individual secara signifikan terhadap minat investasi ditolak.

Selain itu, menggunakan t tabel dan $t$ hitung. Jika $t$ hitung lebih besar daripada $t$ tabel, maka $\mathrm{H} 0$ yang menyatakan pengetahuan investasi, pelatihan pasar modal, 
modal investasi minimal dan persepsi risiko tidak memiliki pengaruh individual terhadap minat investasi ditolak.

\section{Koefisien Determinasi ( $\left.\mathbf{R}^{2}\right)$}

Koefisien determinasi $\left(\mathrm{R}^{2}\right)$ mengukur seberapa jauh kemampuan model dalam menerangkan variasi variabel dependen. Nilai koefisien determinasi adalah antara nol dan satu (Ghozali, 2011).

\section{HASIL PENELITIAN DAN PEMBAHASAN}

\section{Gambaran Umum Obyek Penelitian}

PT Phintraco Sekuritas merupakan perusahaan sekuritas dan anggota Bursa Efek Indonesia yang menyediakan pelayanan Broker-Dealer. Ruang lingkup kegiatan usaha Phintraco Sekuritas meliputi perantara perdagangan efek, penjamin emisi efek dan manajer investasi atau penasehat investasi. PT Phintraco Sekuritas telah bekerja sama dengan 100 perguruan tinggi di Indonesia untuk pendirian Galeri Investasi Bursa Efek Indonesia (GI BEI) dan telah melayani lebih dari 28.000 investor. Salah satu kantor cabang PT Phintraco Sekuritas berada di Semarang yang didirikan pada tanggal 14 Mei 2013. PT Phintraco Sekuritas kantor cabang Semarang telah bekerja sama dengan lima perguruan tinggi di Semarang, diantaranya Universitas Negeri Semarang, Politeknik Negeri Semarang, Universitas PGRI Semarang, Universitas Wahid Hasyim, dan UNIKA Soegijopranoto.

\section{Uji Instrumen Penelitian Uji Validitas}

Penelitian ini terdapat 23 pernyataan kepada 98 responden dan menguji validitas dari seluruh pernyataan tersebut. Kuesioner terbagi menjadi 5 variabel yaitu minat investasi mahasiswa, pengetahuan investasi, pelatihan pasar modal, modal investasi minimal dan persepsi risiko. Variabel minat investasi mahasiswa memiliki 9 indikator, pengetahuan investasi memiliki 3 indikator, pelatihan pasar modal memiliki 3 indikator, modal investasi minimal memiliki 5 indikator dan persepsi risiko 3 indikator. Hasil uji validitas menunjukkan bahwa semua indikator dalam penelitian ini dinyakatan valid atau konsisten.

\section{Uji Reliabilitas}

Hasil uji reliabilitas menunjukkan nilai reliabilitas dengan menggunkan metode Cronbach alpha memberikan nilai lebih dari 0,70 yang menandakan bahwa semua indikator reliabel dan handal untuk digunakan dalam penelitian ini.

\section{Uji Analisis Regresi Linear \\ Berganda \\ Estimasi Model}

Estimasi model regresi ini digunakan untuk mengukur kemampuan variabel independen dalam memprediksi variabel dependen dengan koefisien masingmasing variabel independen. $\mathrm{Di}$ bawah ini merupakan tabel hasil uji regresi linear berganda. 


\section{Coefficientsa}

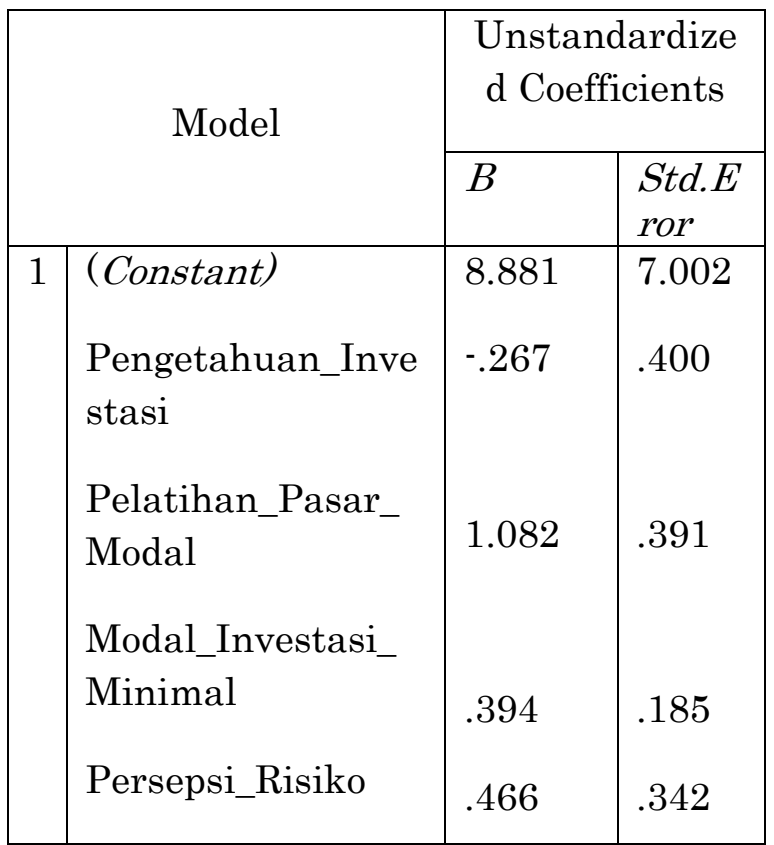

a. Dependent Variable:

Minat_Investasi_Mahasiswa

Sumber: Data primer yang diolah, 2018.

Demikian persamaan regresi linear berganda sebagai berikut:

$\mathrm{MI}=8,881-0,267 \mathrm{PI}+1,082 \mathrm{PPM}+$ $0,394 \mathrm{MIM}+0,466 \mathrm{PR}+\mathrm{e}$

Keterangan:

$$
\begin{array}{ll}
\text { MI } & =\text { Minat Investasi Mahasiswa } \\
\mathrm{PI} & =\text { Pengetahuan Investasi } \\
\mathrm{PPM} & =\text { Pelatihan Pasar Modal } \\
\mathrm{MIM} & =\text { Modal Investasi Minimal } \\
\mathrm{PR} & =\text { Persepsi Risiko } \\
\mathrm{e} & =\text { Error }
\end{array}
$$

\section{Uji Asumsi Klasik}

\section{Uji Linearitas}

Dalam penelitian ini, uji linearitas dilakukan dengan menggunakan Uji Durbin Watson (DW test). Uji Durbin Watson juga digunakan untuk melihat ada tidaknya autokorelasi dalam suatu model regresi. Uji ini digunakan untuk melihat apakah sebaiknya model regresi linear atau kuadrat. Hasil uji Durbin Watson model utama linier adalah sebagai berikut:

\begin{tabular}{|c|c|c|c|c|c|}
\hline \multicolumn{1}{|c|}{ Mod } & & $R$ & & Std. & \\
El & $R$ & Squar & Adjusted & Error of & Durbin- \\
& & & $R$ Square & the & Watson \\
& & $e$ & & Estimate & \\
\hline 1 & $.428^{\mathrm{a}}$ & .184 & .148 & 4.55393 & 1.918 \\
\hline
\end{tabular}

a. Predictors: (Constant),

Persepsi_Risiko,

Pelatihan_Pasar_Modal,

Modal_Investasi_Minimal,

Pengetahuan_Investasi

b. Dependent

Variable:

Minat_Investasi_Mahasiswa

Sumber: Data primer yang diolah, 2018.

Hasil uji Durbin Watson menunjukkan tidak adanya autokolerasi positif pada model dan tidak salah spesifikasi, karena Durbin Watson model utama 1,918 berada di atas $\mathrm{dl}=1,5768$ dengan $\mathrm{n}$ $=98 \mathrm{dan} \mathrm{k}=4$. Jadi, model regresi yang digunakan adalah model linier.

\section{Uji Normalitas}

Model regresi yang baik adalah memiliki distribusi data normal atau mendekati normal. Pengujian normalitas dalam penelitian ini menggunakan analisis grafik dan uji statistik non-parametrik Kolmogorov-Smirnov (K-S).

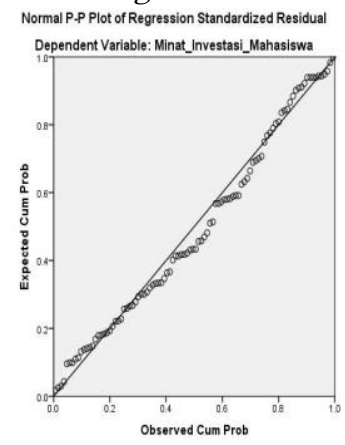

AKUNBISNIS 60 
Sumber: Data primer yang diolah, 2017.

\section{Tampilan Normal Propability} Plot, menunjukkan data menyebar berhimpitan di sepanjang garis diagonal. Hal ini menunjukkan, bahwa residual berdistribusi secara normal.

One-Sample Kolmogorov-

Smirnov Test

\begin{tabular}{|ll|r|}
\hline & $\begin{array}{r}\text { Unstand } \\
\text { ardized } \\
\text { Residual }\end{array}$ \\
\hline$N$ & & 98 \\
Normal & Mean & .0000000 \\
Parameters, & Std. & 4.45904 \\
& Deviation & 529 \\
Most & Absolute & .078 \\
Extreme & Positive & .078 \\
Differences & Negative & -.050 \\
Test Statistic & & .078 \\
Asymp. Sig. & & \\
(2-tailed) & & $.151^{\mathrm{c}}$ \\
\hline
\end{tabular}

a. Test distribution is Normal.

b. Calculated from data.

\section{c. Lilliefors \\ Significance Correction.}

Sumber: Data primer yang diolah, 2018.

Hasil Uji Statistik NonParametric Kolmogorov Smirnov Test (K-S), menunjukkan nilai signifikansi sebesar 0,151 yaitu lebih besar daripada 0,05. Hal ini menunjukkan, bahwa residual terdistribusi secara normal. Dengan demikian dapat disimpulkan, bahwa data penelitian ini berdistribusi normal.

\section{Uji Multikolinieritas}

Nilai cutoff yang dipakai untuk menunjukkan multikolonieritas adalah nilai Tolerance $\leq 0,10$ atau sama dengan nilai VIF $\geq 10$. Hasil uji multikolonieritas dapat dilihat sebagai berikut.

\section{Coefficients ${ }^{a}$}

\begin{tabular}{|l|c|c|}
\hline \multirow{2}{*}{\multicolumn{1}{|c|}{ Model }} & \multicolumn{2}{c|}{ Collinearity } \\
& \multicolumn{2}{|c|}{ Statistic } \\
\cline { 2 - 3 } & Toleranc & \\
& & VIF \\
\hline (Constant) & & \\
Pengetahuan_Investasi & .734 & 1.362 \\
Pelatihan_Pasar_Modal & .719 & 1.390 \\
Modal_Investasi_Minim & & \\
al & .882 & 1.134 \\
Persepsi_Risiko & .941 & 1.063 \\
& & \\
\hline
\end{tabular}

a. Dependent Variable:

Minat_Investasi_Mahasiswa Sumber: Data primer yang diolah, 2018.

Hasil perhitungan nilai Tolerance tidak ada independen yang memiliki nilai Tolerance $\leq$ 0,10 . Hasil perhitungan nilai VIF juga menunjukkan tidak ada variabel independen yang memiliki nilai VIF $\geq 10$

Dengan demikian dapat disimpulkan, bahwa tidak adanya multikolonieritas antar variabel independen dalam model regresi penelitian ini.

\section{Uji Heteroskedastisitas}

Dalam penelitian ini untuk mendeteksi ada tidaknya heteroskedastisitas ilakukan dengan melihat ada tidaknya pola tertentu pada grafik scatterplot. 


\begin{tabular}{|cl|c|c|}
\hline \multicolumn{1}{|c|}{ Model } & T & Sig. \\
\hline 1 (Constant) & .331 & .741 \\
$\begin{array}{l}\text { Pengetahuan_Inv } \\
\text { estasi }\end{array}$ & -.024 & .981 \\
$\begin{array}{l}\text { Pelatihan_Pasar_- } \\
\text { Modal }\end{array}$ & .497 & .620 \\
& Modal_Investasi_- & \\
& Minimal & .263 & .793 \\
& Persepsi_Risiko & .028 & .978 \\
\hline
\end{tabular}

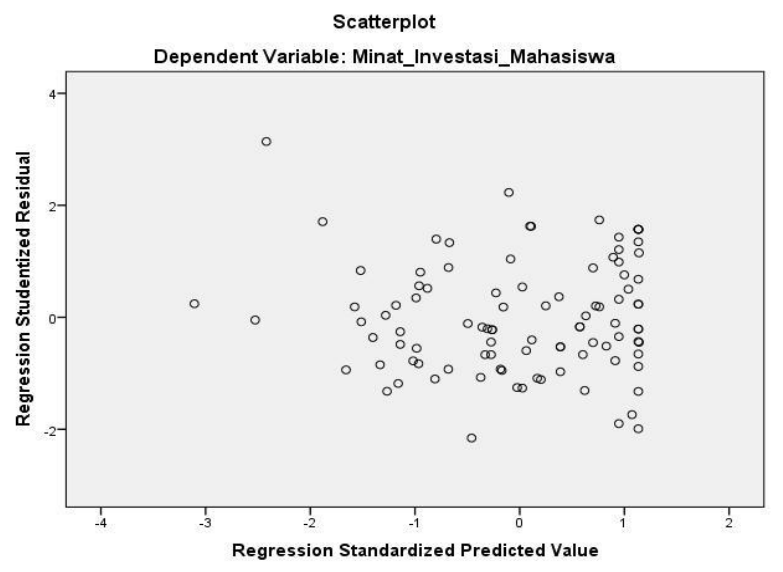

Sumber: Data primer yang diolah, 2018

Berdasarkan hasil uji heteroskedastisitas melalui grafik scarrplots menunjukkan bahwa, dalam penelitian ini tidak terjadi heteroskedastisistas. Hal ini ditunjukkan dari grafik scatterplots terlihat titik-titik menyebar secara acak serta tersebar baik di atas maupun di bawah angka 0 pada sumbu Y. Analisis dengan grafik plots memiliki kelemahan yang cukup signifikan, karena jumlah pengamatan mempengaruhi hasil plotting. Oleh karena itu, dalam penelitian ini dilakukan uji statistik yang lebih dapat menjamin keakuratan hasil dengan uji

glejser.

\section{Coefficients ${ }^{a}$ \\ a. Dependent Variable: \\ $\mathrm{AbsUt}$}

Sumber: Data primer yang

diolah, 2018

Berdasarkan uji glejser, tidak ada variabel independen yang signifikan secara statistik mempengaruhi variabel dependen nilai Absolut $U t\left(A b_{s} U t\right)$, karena nilai signifikansi (Sig.) semua variabel independen lebih besar dari 0,05 . Dengan demikian dapat disimpulkan, penelitian ini tidak terjadi heteroskedastisitas.

\section{Uji Kelayakan Model}

Uji F

\begin{tabular}{|c|c|c|c|c|c|}
\hline \multicolumn{6}{|c|}{ ANOVAa $^{a}$} \\
\hline Model & $\begin{array}{c}\text { Sum of } \\
\text { Squares }\end{array}$ & $D f$ & $\begin{array}{l}\text { Mean } \\
\text { Square }\end{array}$ & $F$ & Sig. \\
\hline 1 & & & 108.39 & & \\
\hline Regression & 433.586 & 4 & 6 & 5.2 & .001 \\
\hline Resid & 1928.65 & & & & \\
\hline ual & 9 & 93 & 20.738 & 27 & \\
\hline Total & 5 & 97 & & & \\
\hline
\end{tabular}

a. Dependent Variable:

Minat_Investasi_Mahasisw

a b. Predictors: (Constant),

Persepsi_Risiko,

Pelatihan_Pasar_Modal,

Modal_Investasi_Minimal,

Pengetahuan_Investasi

b. Sumber: Data primer yang

diolah, 2018. 
Dalam penelitian ini menunjukkan F hitung $(5,227)>$ menunjukkan model memiliki goodness of fit yang baik, karena pengetahuan investasi, pelatihan pasar modal, modal investasi minimal dan persepsi risiko berpengaruh secara simultan terhadap kepuasan nasabah. Selain itu, tingkat signifikansinya
F tabel $(2,47)$. Hal ini

sebesar $0,001<0,05$, yang berarti pengaruh pengetahuan investasi, pelatihan pasar modal, modal investasi minimal dan persepsi risiko adalah signifikan. Dengan demikian, model penelitian layak untuk digunakan sebagai model pemecahan masalah penelitian.

\section{Uji t}

\begin{tabular}{|c|c|c|c|c|c|}
\hline \multirow[t]{2}{*}{ Model } & \multicolumn{2}{|c|}{$\begin{array}{l}\text { Unstandardized } \\
\text { Coefficients } \\
e\end{array}$} & \multirow{2}{*}{\begin{tabular}{|c|}
$\begin{array}{c}\text { Standar } \\
\text { dized } \\
\text { Coeffien } \\
\text { ts. }\end{array}$ \\
Beta \\
\end{tabular}} & \multirow[t]{2}{*}{$t$} & \multirow[t]{2}{*}{ Sig. } \\
\hline & $B$ & $\begin{array}{l}\text { Std. } \\
\text { Error }\end{array}$ & & & \\
\hline \multirow{2}{*}{$\begin{array}{ll}1 & (\text { Constant }) \\
& \text { Pengetahua } \\
& \text { n_Investasi } \\
\end{array}$} & 8.881 & 7.002 & & 1.268 & .208 \\
\hline & $-0,267$ & 0.400 & -.073 & $\begin{array}{l}-.667 \\
\end{array}$ & .507 \\
\hline $\begin{array}{l}\text { Pelatihan_ } \\
\text { Pasar_Mod }\end{array}$ & 1.082 & .391 & .306 & 2.770 & .007 \\
\hline $\begin{array}{l}\text { Modal_Inv } \\
\text { estasi_Mini } \\
\text { mal }\end{array}$ & .3944 & .185 & .212 & 2.128 & .036 \\
\hline $\begin{array}{l}\text { Persepsi_R } \\
\text { isiko }\end{array}$ & .466 & .342 & .132 & 1.362 & .176 \\
\hline
\end{tabular}

a. Dependen Variable: Minat_Investasi_Mahasiswa

Sumber: Data primer yang diolah, 2018.

Hasil uji $t$ menunjukkan, pengetahuan investasi dan persepsi risiko tidak berpengaruh terhadap minat investasi mahasiswa, sedangkan penelitihan pasar modal dan modal investasi minimal berpengaruh terhadapminat investasi mahasiswa. Hal ini ditunjukkan dengan nilai t hitung lebih kecil dari t tabel dan signifikansi lebih dari 0,05 untuk pengetahuan investasi persepsi risiko, sedangkan untuk pelatihan pasar modal dan modal investasi minimal memiliki nilai $t$ hitung yang lebih besar dari t tabel dan signifikansi kurang dari 0,05.

\section{Uji Koefisien Determinasi ( $\left.\mathrm{R}^{2}\right)$}

Dalam penelitian ini, untuk mengukur pengetahuan investasi, pelatihan pasar modal, modal investasi minimal dan persepsi risiko digunakan nilai adjusted $\mathrm{R}^{2}$. Hal tersebut dikarenakan, nilai adjusted $\mathrm{R}^{2}$ memiliki kebiasan nilai yang kecil dibandingkan nilai $\mathrm{R}^{2}$. 


\section{Pembahasan Pengujian Hipotesis Pengujian Hipotesis Satu (H1)}

Model Summary

\begin{tabular}{|c|c|c|c|c|}
\hline & & $R$ & & $\begin{array}{c}\text { Std. } \\
\text { Error of }\end{array}$ \\
& & Squar & $\begin{array}{l}\text { Adjuste } \\
d \\
R\end{array}$ & the \\
Model & $R$ & $e$ & Square & Estimat \\
\hline 1 & $\begin{array}{l}.428 \\
\text { a }\end{array}$ & .184 & .148 & 4.5539 \\
\hline
\end{tabular}

a. Predictors: (Constant),

Persepsi_Risiko,

Pelatihan_Pasar_Modal,

Modal_Investasi_Minimal,

Pengetahuan_Investasi

b. Dependent

Variable:

Minat_Investasi_Mahasiswa

Sumber: Data primer yang diolah, 2018.

Hal ini menunjukkan, bahwa model penelitian yang diajukan memiliki kelayakan yang rendah, karena kemampuan variabel independen yang digunakan yaitu pengetahuan investasi, pelatihan pasar modal, modal investasi minimal dan persepsi risiko dalam menjelaskan variabel dependennya yaitu minat investasi hanya sebesar 0,148 atau $14,8 \%$, sedangkan 0,852 atau $85,2 \%$ dijelaskan oleh variabel independen lain. Variabel independen selain dalam penelitian ini seperti penghasilan (Merawati dan Putra, 2015); return, gender dan kemajuan teknologi (Tandio dan Widanaputra, 2016); manfaat investasi dan motivasi investasi (Hermanto, 2017); pendapatan dan belajar (Malik, 2017).
Berdasarkan hasil uji $t$ menunjukkan, bahwa hipotesis yang menyatakan pengetahuan investasi berpengaruh terhadap ninat investasi mahasiswa Durbinelitolak. Hasil penelitian ini sesuai dengan penelitian Malik (2017) Watsory ang menunjukkan, pengetahuan ipvestasi berpengaruh negatif 1.918 rhadap minat investasi masyarakat di pasar modal syariah melalui bursa galeri investasi Universitas Internasional Semen Indonesia (UISI).

Selain itu, dikarenakan responden dalam penelitian ini merupakan mahasiswa yang telah membuka rekening investasi di PT Phintraco Sekuritas Branch Office Semarang, sehingga penambahan pengetahuan investasi dianggap tidak terlalu penting oleh responden. Hal ini disebabkan responden telah mengetahui dasar-dasar investasi sebelum membuka rekening investasi di PT Phintraco Sekuritas Branch Office Semarang, sehingga penambahan pengetahuan investasi tidak berpengaruh terhadap minat investasi mahasiswa di pasar modal.

\section{Pengujian Hipotesis Dua (H2)}

Berdasarkan hasil uji $t$ menunjukkan, bahwa nilai t hitung $>\mathrm{t}$ tabel $(2,770>1,9855)$ dan signifikansinya di bawah 0,05 yaitu 0,007. Hal ini menunjukkan, bahwa hipotesis yang menyatakan pelatihan pasar modal berpengaruh terhadap minat investasi mahasiswa 
diterima. Hasil penelitian ini sejalan dengan hasil penelitian yang dilakukan oleh Tandio dan Widanaputra (2016), bahwa pelatihan pasar modal berpengaruh terhadap minat investasi mahasiswa.

Hasil penelitian ini juga didukung dengan pencapaian PT Phintraco Sekuritas yang telah memiliki 100 Galeri Investasi, dan mendapatkan penghargaan Rekor Museum Rekor Indonesia (MURI) 2018 sebagai perusahaan sekuritas yang memiliki Galeri Investasi terbanyak pada tanggal 18 Mei 2018 http://(www.phintraco.com)

\section{Pengujian Hipotesis Tiga (H3)}

Berdasarkan hasil uji $t$ menunjukkan, bahwa nilai t hitung $>\mathrm{t}$ tabel $(2,128>1,9855)$ dan signifikansinya di bawah 0,05 yaitu 0,036. Hal ini menunjukkan, bahwa hipotesis yang menyatakan modal investasi minimal berpengaruh terhadap minat investasi mahasiswa diterima. Hasil penelitian ini sejalan dengan hasil penelitian Nisa dan Zulaika (2017), bahwa modal minimal investasi berpengaruh terhadap minat investasi mahasiswa.

Hasil penelitian ini juga didukung dengan kebijakan PT Phintraco Sekuritas yaitu dana awal yang harus disetorkan untuk membuat account hanya dengan Rp100.000,00. Selain itu, berdasarkan Keputusan Direksi PT Bursa Efek Indonesia yang tercantum pada Kep-00005/BEI/012011, memberikan kebijakan satuan perdagangan saham di Indonesia, 1 lot setara dengan 100 lembar saham (www.phintraco.com).

\section{Pengujian Hipotesis Empat (H4)}

Berdasarkan hasil uji $t$ menunjukkan, bahwa nilai t hitung $<\mathrm{t}$ tabel $(1,362<1,9855)$ dan signifikansinya di atas 0,05 yaitu 0,176 . Hal ini menunjukkan, bahwa hipotesis yang menyatakan persepsi risiko berpengaruh terhadap minat investasi mahasiswa ditolak. Hasil penelitian ini sejalan dengan hasil penelitian Tandio dan Widanaputra (2016), bahwa persepsi risiko tidak berpengaruh terhadap minat investasi mahasiswa.

Selain itu, dikarenakan responden dalam penelitian ini merupakan mahasiswa yang telah membuka rekening investasi di PT Phintraco Sekuritas Branch Office Semarang, sehingga pembelajaran maupun pertimbangan berkaitan dengan risiko dianggap tidak terlalu penting. Dengan kata lain, responden merupakan mahasiswa yang berani mengambil risiko dalam berinvestasi, sehingga perubahan presepsi risiko tidak berpengaruh terhadap minat investasi mahasiswa di pasar modal.

Hasil penelitian ini juga didukung dengan pernyataan Raditya dkk (2014), bahwa seseorang cenderung mengabaikan risiko, jika hal yang dipertaruhkan nilainya tidak besar. Sebaliknya, jika nilainya besar, maka bisa dipastikan setiap orang akan berusaha semaksimal mungkin untuk menekan risiko.

\section{Interpretasi Model}

Konstanta $=8,881$

Hal ini berarti, jika pengaruh variabel pengetahuan investasi, pelatihan pasar modal, modal investasi minimal dan persepsi risiko sama dengan nol, maka 
variabel minat investasi mahasiswa sebesar 8,881 .

\section{Koefisien PI $=-0,267$}

Koefisien regresi pengetahuan investasi terhadap minat investasi mahasiswa sebesar - 0,267 yang menunjukkan, bahwa ketika PT Phintraco Sekuritas Branch Office Semarang memberikan pengetahuan investasi, maka minat investasi mahasiswa PT Phintara Sekuritas Branch Office Semarang akan menurun sebesar 0,267.

\section{Koefisien PPM = 1,082}

Koefisien regresi pelatihan pasar modal terhadap minat investasi mahasiswa sebesar 1,082 yang menunjukkan, bahwa ketika PT Phintraco Sekuritas Branch Office Semarang memberikan pelatihan pasar modal yang dinilai penting bagi mahasiswa, maka minat investasi mahasiswa PT Phintraco Sekuritas Branch Office Semarang akan meningkat menjadi 1,082 .

\section{Koefisien MIM = 0,394}

Koefisien regresi modal investasi minimal terhadap minat investasi mahasiswa sebesar 0,394 yang menunjukkan, bahwa ketika PT Phintraco Sekuritas Branch Office Semarang menurunkan modal investasi minimal yang dinilai penting bagi mahasiswa, maka minat investasi mahasiswa PT Phintraco Sekuritas Branch Office Semarang akan meningkat menjadi 0,394 .

\section{Koefisien PR $=0,466$}

Koefisien regresi persepsi risiko terhadap minat investasi mahasiswa sebesar 0,466 yang menunjukkan, bahwa ketika PT Phintraco
Sekuritas Branch Office Semarang menurunkan persepsi risiko yang dinilai penting bagi mahasiswa, maka minat investasi mahasiswa di pasar modal PT Phintraco Sekuritas Branch Office Semarang meningkat menjadi 0,466.

\section{PENUTUP}

\section{Kesimpulan}

Berdasarkan hasil analisis dan pembahasan yang telah dilakukan dalam penelitian ini mengenai analisis pengaruh pengetahuan investasi, pelatihan pasar modal, modal investasi minimal dan persepsi risiko terhadap minat investasi mahasiswa pada PT Phintraco Sekuritas Branch Office Semarang, maka kesimpulan yang diambil adalah sebagai berikut:

Hasil uji instrumen penelitian yaitu uji validitas dan uji reliabilitas menunjukkan, bahwa semua indikator-indikator yang digunakan untuk mengukur variabel independen dan variabel dependen dalam penelitian ini layak dan handal sebagai tolok ukur.

Hasil uji estimasi model menghasilkan model regresi linear berganda sebagai berikut:

$$
\begin{aligned}
\mathrm{MI}=8,881-0,267 \mathrm{PI}+1,082 \\
\\
\mathrm{PPM}+0,394 \\
\mathrm{MIM}+0,466 \mathrm{PR} \\
+\mathrm{e}
\end{aligned}
$$

Hasil uji asumsi klasik yaitu uji linearitas, uji normalitas, uji multikolonieritas dan uji heteroskedastisitas menunjukkan, bahwa model penelitian yang dikembangkan memenuhi syarat asumsi klasik sebagai model regresi yang baik. 
Hasil uji kelayakan model yaitu uji $\mathrm{F}$ menunjukkan, bahwa model penelitian layak untuk digunakan sebagai model pemecahan masalah penelitian.

Hasil pengujian hipotesis satu (H1) yang diperoleh dari uji $\mathrm{t}$ menunjukkan, pengetahuan investasi tidak berpengaruh terhadap minat investasi mahasiswa di pasar modal pada PT Phintraco Sekuritas Branch Office Semarang.

Hasil pengujian hipotesis dua (H2) yang diperoleh dari uji $\mathrm{t}$ menunjukkan, pelatihan pasar modal berpengaruh terhadap minat investasi mahasiswa di pasar modal pada PT Phintraco Sekuritas Branch Office Semarang.

Hasil pengujian hipotesis tiga (H3) yang diperoleh dari uji $t$ menunjukkan, modal investasi minimal berpengaruh terhadap minat investasi mahasiswa di pasar modal pada PT Phintraco Sekuritas Branch Office Semarang.

Hasil pengujian hipotesis empat (H4) yang diperoleh dari uji $t$ menunjukkan, persepsi risiko tidak berpengaruh terhadap minat investasi mahasiswa di pasar modal pada PT Phintraco Sekuritas Branch Office Semarang.

\section{Saran}

Model ini menunjukkan, bahwa PT Phintraco Sekuritas Branch Office Semarang sebaiknya berfokus pada pelatihan pasar modal dalam upaya meningkatkan minat investasi mahasiswa. Hal ini disebabkan, pelatihan pasar modal memiliki pengaruh terhadap minat investasi mahasiswa dan pengaruhnya berdampak paling besar pada perubahan minat investasi mahasiswa dibandingkan

\begin{abstract}
dengan variabel lainnya. Sumbangan kebijakan terkait dengan pelatihan pasar modal yang disarankan antara lain:
\end{abstract}

Pelatihan pasar modal yang terstruktur dan metode yang berbeda. Hal ini dimaksudkan, agar mahasiswa mendapatkan pelatihan secara bertahap dari yang paling mudah hingga yang tersulit. Dengan demikian, mahasiswa semakin bersemangat mengikuti pelatihan pasar modal dan akan menambah ketertarikannya untuk berinvestasi di pasar modal pada PT Phintraco Sekuritas Branch Office Semarang.

Mengadakan kelas pasar modal tentang tata cara berinvestasi yang mudah dan murah di berbagai perguruan tinggi. Hal ini dikarenakan, dengan diadakannya kelas sekolah pasar modal tersebut, mahasiswa akan semakin memahami bagaimana berinvestasi yang benar dan menguntungkan. Dengan demikian, mahasiswa akan semakin tertarik untuk berinvestasi di pasar modal pada PT Phintraco Sekuritas Branch Office Semarang.

PT Phintraco Sekuritas Branch Office Semarang bekerja sama dengan dosen pengajar perguruan tinggi yang telah didirikan galeri investasi. Hal ini dikarenakan, dosen dapat membantu memberikan simulasi investasi kepada mahasiswa sebagai bentuk dari pelatihan pasar modal. Dengan demikian, mahasiswa akan semkain penasaran dan tertarik untuk melakukan investasi di pasar modal.

\section{Keterbatasan Penelitian}

Keterbatasan dalam penelitian ini adalah sebagai berikut:

Dari hasil uji estimasi model 
regresi yang menunjukkan hasil negatif variabel pengetahuan investasi, serta dari uji estimasi model regresi menunjukkan variabel pengetahuan investasi memiliki prediksi yang rendah terhadap minat investasi mahasiswa. Hal ini ditunjukkan dengan besarnya koefisien regresi sbesar -0,267. Arah dari koefisien regresi tersebut adalah negatif, dengan kemampuan prediksinya -0,267. Hasil ini merupakan keterbatasan pengetahuan investasi untuk memprediksi minat investasi mahasiswa, yang dapat disebabkan karena penentuan indikatorindikator yang kurang sesuai dengan mahasiswa yang membuka rekening efek di PT Phintraco Sekuritas Branch Office Semarang, seperti pembelajaran dasar investasi, pemberian edukasi investasi dan pengadaan sekolah pasar modal.

Mengingat terbatasnya waktu, biaya dan tenaga, sehingga jurnal yang digunakan untuk mendukung penelitian ini relatif sedikit. Selain itu, karena keterbatasan waktu, biaya dan tenaga menyebabkan variabel penelitian menggunakan 4 (empat) variabel bebas yaitu pengetahuan investasi, pelatihan pasar modal, modal investasi minimal dan persepsi risiko untuk mengetahui pengaruhnya terhadap minat investasi mahasiswa.

\section{DAFTAR PUSTAKA}

Fahmi, Irham. 2012. Pengantar

Pasar Modal. Cetakan Ke-2.

Bandung: Alfabeta.

Ghozali, Imam. 2011. Aplikasi

Analisis Multivariate dengan Program SPSS,

Semarang: Badan Penerbit
UNDIP.

Halim, Abdul. 2005. Analisis

Investasi. Jakarta: PT Salemba Emban Patria.

Hasan, Iqbal. 2010. Analisa Data Penelitian dengan Statistik. Jakarta: PT Bumi Aksara

Hermanto. 2017. "Perilaku Mahasiswa Ekonomi di Universitas Esa Unggul dalam Melakukan Investasi di Pasar Modal". Jurnal Ekonomi. Volume 8 Nomor 2.

Khotimah et al. 2016. "Pengaruh Sosialisasi dan Pengetahuan Terhadap Minat Investor Pada Efek Syariah di Pasar Modal (Survei Pada Nasabah PT Danareksa Sekuritas Cabang FEUI Depok)". Volume 1. Nomor 5. Juni 2016. Politeknik Negeri Jakarta.

KSEI. 2017. KSEI Terus Upayakan Kemudahan Pembukaan

Rekening Investor Investor. http://www.ksei.co.id/files/upload/ press releases/id

id/135 berita pres ksei terus up ayakan_kemudah

an_pembukaan_rekening_investa si_201708161542 $08 \quad$ (12

Desember 2017).

Kusmawati. 2011. "Pengaruh Motivasi Terhadap Minat Berinvestasi di Pasar Modal dengan Pemahaman Investasi dan Usia sebagai Variabel Moderat".

\section{Jurnal Ekonomi dan Informasi Akuntansi (JENIUS). Volume 1. Nomor 2. Mei 2011. STIE MUSI}


Palembang.

Malik, Ahmad. 2017. "Analisa Faktor - Faktor yang Mempengaruhi Minat Masyarakat Berinvestasi di Pasar Modal Syariah melalui Bursa Galeri Investasi UISI".

Jurnal Ekonomi dan Bisnis Islam. Volume 3. Nomor 1. Januari-Juni. Universitas Internasional Semen Indonesia.

Merawati dan Putra. 2015. "Kemampuan Pelatihan Pasar Modal Memoderasi Pengaruh Pengetahuan Investasi dan Penghasilan pada Minat Berinvestasi Mahasiswa”. Jurnal Ilmiah Akuntansi dan Bisnis. Volume 10. Nomor 2. 2016. "Dampak

Pelatihan Pasar Modal Terhadap Pengetahuan Investasi dan Minat Berinvestasi Mahasiswa".

Prosding Seminar Nasional Hasil Penelitian. ISBN: 978-602-728945-1.

Nazir, Moh. 2005. Metode Penelitian. Bogor: Ghalia Indonesia.

Newswire. 2017. Investor Pasar Modal di BEI Semarang Didominasi Mahasiswa. http://semarang.bisnis.com/read/2 0170308/3/92593/ investor-pasarmodal-di-bei-semarangdidominasi- mahasiswa, (14 Januari 2018).

Nisa dan Zulaika. 2017. "Pengaruh Pemahaman Investasi, Modal Minimal Investasi dan Motivasi Terhadap Minat Mahasiswa
Berinvestasi di Pasar Modal". Jurnal Penelitian Teori dan Terapan Akuntansi (PETA). Volume 2. Nomor 2. Juli.

Pajar dan Pustikaningsih. 2017. "Pengaruh Motivasi Investasi dan Pengetahuan Investasi Terhadap Minat Investasi di Pasar Modal pada Mahasiswa FE UNY". Jurnal Profita Edisi 1. Universitas Negeri Yogyakarta.

Raditya et al. 2014. "Pengaruh Modal Investasi Minimal di BNI Sekuritas, Return dan Persepsi Terhadap Risiko pada Minat Investasi Mahasiswa, dengan Penghasilan sebagai Variabel Moderasi (Studi Kasus pada Mahasiswa Magister di Fakultas Ekonomi dan Bisnis Universitas Udayana)". E-Jurnal Ekonomi dan Bisnis Universitas Udayana 3.7.

Sekuritas, Phintraco. 2016. Member of Indonesia Stock Exchange. www.phintracosekuritas.com, (30Desember 2017).

Sugiyono. 2010. Metode Penelitan Bisnis. Bandung: Alfabeta.

Suhir dkk. 2014. "Pengaruh Persepsi Rsiko, Kemudahan dan Manfaat Terhadap Keputusan pembelian Secara Online (Survei Terhadap pengguna Situr Website www.kaskus.co.id)".

Jurnal Administrasi Bisnis (JAB). Volume. 8. Nomor 8. 1 Februari. Universitas Brawijaya Malang.

Tandelilin, Eduardus. 2017. Portofolio dan Investasi Teori dan Aplikasi. Yogyakarta: PT 
Kanisius.

Tandio dan Windanaputra. 2016.

"Pengaruh Pelatihan Pasar Modal, Return, Persepsi Risiko, Gender, dan Kemajuan Teknologi Pada Minat Investasi Mahasiswa". E-Jurnal Akuntansi Universitas Udayana. Volume 16.3 .

Wiyono, Gendro. 2011. 3 in One Merancang Penelitian Bisnis dengan Alat Analisis SPSS 17.0 \& SmartPLS 2.0. YKPN: Yogyakarta.

Wulandari dan Iramani. 2014. "Studi

Experienced Regret, Risk Tolerance, Overconfidance dan Risk Perception pada Pengambilan Keputusan Investasi Dosen Ekonomi”. Journal of Business and Banking. Volume 4, Nomor 1. Mei 2014. ISSN 2088-7841. STIE Perbanas Surabaya.

Yuliati, Lilis. 2011. "Faktor-Faktor yang Mempengaruhi Minat Masyarakat Berinvestasi Sukuk". Jurnal Walisongo. Volume 19. Nomor 1. Mei 2011. Universitas Jember. 